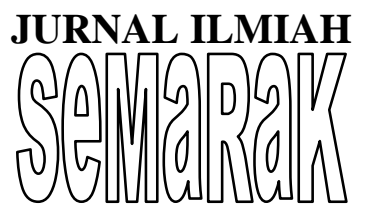

P-ISSN 2615-6849, E-ISSN 2622-3686

Jurnal Semarak,Vol. 3,No.1, Februari 2020, Hal (60- 74)

@Prodi Manajemen Fakultas Ekonomi Universitas Pamulang

\title{
PENGARUH PERKEMBANGAN TEKNOLOGI INFORMASI DAN FAKTOR KELUARGA TERHADAP PRESTASI BELAJAR SISWA SEKOLAHDASAR (Study Kasus Di Kecamatan Pondok Betung, Tangerang Selatan)
}

\author{
BUDHI PRABOWO ${ }^{1}$, ANGGA JUANDA, IBRAHIM BALI PAMUNGKAS
}

Email: bowieprabudhi@gmail.com

\begin{abstract}
ABSTRAK
Seiring pesatnya era digitalisasi,perkembangan teknologi informasi dalam gadget dan aplikasi yang terkandung didalamnya seperti youtube dan game online juga mengalami perkembangan. Game Online menyajikan tantangan yang lebih bervariasi dibandingkan dengan game offline, Game online bersifat seduktif yang berarti dapat menyebabkan kecanduan, Kecanduan game online ditandai oleh sejauh mana seseorang bermain game secara berlebihan sehingga dapat mengganggu aktifitas seharihari.Game online bersifat sangat seduktif yang berarti dapat menyebabkan kecanduan karena memiliki daya tarik dan tingkat keseruan yang tinggi. Seseorang yang mengalami kecanduan game online menganggap bahwa bermain adalah suatu kebutuhan prioritas dimana ketika mereka berhenti bermain maka akan merasakan keadaan gelisah, cemas, dan Nampak murung dan menganggap game online adalah sarana penghibur diri dari sesuatu masalah yang sedang dialami.

Metode yang digunakan dalam penelitian ini adalah kuantitatif yang bersifat deskriptif analisis. Maka dilakukan pengujian statistic untuk mengukur seberapa besar pengaruh diantara variabel-variabel yang diteliti dan proses perhitungan statistic. Sedangkan populasi dalam penelitian ini adalah Sekolah Dasar Negeri di wilayah Tangerang Selatan, merupakan objek yang dipilih oleh peneliti dan yang menjadi subjek penelitiannya adalah siswa kelas 4 yang berjumlah 128 orang dan semua anggota populasi merupakan random sampling untuk penentuan responden. Hasil penelitian ini menunjukan bahwa Terdapat pengaruh positif dan signifikan secara parsial antara Teknologi Informasi $\left(\mathrm{X}_{1}\right)$ terhadap Prestasi Belajar $(\mathrm{Y}) . \mathrm{Y}=\mathrm{a}+\mathrm{b}(\mathrm{X})$ adalah $\mathrm{Y}=16,298+0,599\left(\mathrm{x}_{1}\right)$. Terdapat pengaruh positif dan signifikan secara secara parsial antara Faktor Keluarga $\left(\mathrm{X}_{2}\right)$ terhadap Prestasi Belajar $(\mathrm{Y}) . \mathrm{Y}=\mathrm{a}+\mathrm{b}(\mathrm{x})$ adalah $\mathrm{Y}=14,445$ $+0,637\left(\mathrm{x}_{2}\right)$. Terdapat pengaruh positif dan signifikan secara simultan antara Teknologi Informasi $\left(\mathrm{X}_{1}\right)$ dan Faktor Keluarga $\left(\mathrm{X}_{2}\right)$ terhadap Prestasi Belajar $(\mathrm{Y})$. persamaan regresi linear berganda $\mathrm{Y}=\mathrm{a}+\mathrm{b}_{1} \mathrm{x}_{1}+$ $\mathrm{b}_{2} \mathrm{x}_{2}$ adalah $\mathrm{Y}=8,241+0,391\left(\mathrm{x}_{1}\right)+0,417\left(\mathrm{x}_{2}\right)$.
\end{abstract}

Simpulan dari hasil penelitian yaitu pengaruh yang positif dan signifikan antara teknologi informasi dan faktor keluarga terhadap prestasi belajar baik secara parsial maupun secara simultan.

Kata Kunci: Teknologi Informasi, Faktor Keluarga dan Prestasi Belajar 
JURNAL ILMIAH

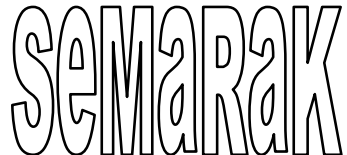

P-ISSN 2615-6849, E-ISSN 2622-3686

Jurnal Semarak,Vol. 3,No.1, Februari 2020, Hal (60- 74)

@Prodi Manajemen Fakultas Ekonomi Universitas Pamulang

\begin{abstract}
Along with the rapid era of digitalization, the development of information technology in gadgets and applications contained in it such as YouTube and online games are also experiencing growth. Online games present more varied challenges compared to offline games, online games are seductive which means it can cause addiction, online game addiction is characterized by the extent to which someone plays games excessively so that they can interfere with daily activities. Online games are very seductive which means they can cause addiction because they have a high level of appeal and excitement. Someone who is addicted to online games considers that playing is a priority need where when they stop playing they will feel anxious, anxious, and seem gloomy and assume online gaming is a means of comforting themselves from something that is being experienced.

The method used in this research is quantitative descriptive analysis. Then carried out statistical testing to measure how much influence between the variables studied and the statistical calculation process. Whereas the population in this study was the Public Elementary School in the South Tangerang region, which was the object chosen by the researcher and the subject of the study was the fourth grade students totaling 128 people and all members of the population were random sampling for the determination of respondents. The results of this study indicate that there is a positive and partially significant effect between Information Technology (X1) on Learning Achievement $(Y) . Y=a+b(X)$ is $Y$ $=16,298+0.599(x 1)$. There is a positive and partially significant effect between Family Factors (X2) on Learning Achievement $(Y) . Y=a+b(x)$ is $Y=14.445+0.637(x 2)$. There is a positive and significant effect simultaneously between Information Technology (X1) and Family Factors (X2) on Learning Achievement $(Y)$. The multiple linear regression equation $Y=a+b 1 x 1+b 2 x 2$ is $Y=8,241+0,391(x 1)$ $+0,417(x 2)$.
\end{abstract}

Conclusions from the results of the study are positive and significant effects between information technology and family factors on learning achievement both partially and simultaneously.

\title{
Keywords: Information Technology, Family Factors and Learning Achievement
}

\section{A. Pendahuluan}

Seiring pesatnya era digitalisasi, perkembangan teknologi informasi dalam gadget dan aplikasi yang terkandung didalamnya seperti youtube dan game online juga mengalami perkembangan. Game Online menyajikan tantangan yang lebih bervariasi dibandingkan dengan game offline, hal ini membuat para pemain betah dan bermain cukup lama. Game online bersifat seduktif yang berarti dapat menyebabkan kecanduan, Kecanduan game online ditandai oleh sejauh mana seseorang bermain game secara berlebihan sehingga dapat mengganggu aktifitas sehari-hari. 
Game online bersifat sangat seduktif yang

berarti dapat menyebabkan kecanduan karena memiliki daya tarik dan tingkat keseruan yang tinggi. Seseorang yang mengalami kecanduan game online menganggap bahwa bermain adalah suatu kebutuhan prioritas dimana ketika mereka berhenti bermain maka akan merasakan keadaan gelisah, cemas, dan Nampak murung dan menganggap game online adalah sarana penghibur diri dari sesuatu masalah yang sedang dialami.

Game online sangat diminati oleh anakanak dan remaja khususnya laki-laki, karena alur ceritanya yang dapat menciptakan ketegangan dan kesenangan dalam menyelesaikan sebuah misi permainan. Alur cerita ini membuat seseorang yang sedang bermain akan terus bersemangat sampai menyelesaikan memenangkan game tersebut.

Dari survey awal yang sudah dilakukan oleh peneliti, menunjukkan bahwa sebagian besar dari populasi sangat meminati game online. Rata-rata mereka memang menghabiskan waktu 1 - 4 jam untuk beberapa pertandingan. Tidak sedikit pula yang menghabiskan waktu 5 jam untuk bermain, bahkan ada yang lebih dari 5 jam dalam sehari untuk bermain game. Jika dicermati dengan baik, tidak ada unsure pendidikan apapun yang bisa didapatkan dari game online. Memang tidak semua siswa menggunakan internet hanya untuk bermain game, di antara mereka juga ada yang menggunakan internet untuk sarana mencari pengetahuan dan mengerjakan tugas dari gurunya, namun yang melakukan hal tersebut jumlahnya tidak terlalu banyak.
Sekolah Dasar Negeri di wilayah Tangerang Selatan, merupakanobjek yang dipilih oleh peneliti dan yang menjadi subjek penelitiannya adalah siswakelas 4. Pada saat jam sekolahatau saat pulang sekolah siswa sering sekali mengajak temannya untuk bermain game online. Berdasarkan latarbelakang di atas, peneliti ingin melakukan penelitian yang berjudul "PENGARUH PERKEMBANGAN TEKNOLOGI INFORMASI DAN FAKTOR KELUARGA TERHADAP PRESTASI BELAJAR SISWA SEKOLAH DASAR DI KECAMATAN PONDOK BETUNG, TANGERANG SELATAN".

\section{B. Kajian Pustaka}

\section{PengertianPrestasiBelajar}

Pengertian yang lebih umum mengenai prestasi belajar ini dikemukakan oleh Moh. Surya (2004), yaitu "prestasi belajar adalah hasil belajar atau perubahan tingkah laku yang menyangkut ilmu pengetahuan, keterampilan dan sikap setelah melalui proses tertentu, sebagai hasil pengalaman individu dalam interaksi dengan lingkungannya”.

Pengertian prestasi belajar sebagaimana tercantum dalam Kamus Besar Bahasa Indonesia (2001) "Prestasi balajar adalah penguasaan pengetahuan atau keterampilan yang dikembangkan melalui mata pelajaran, lazimnya ditunjukan dengan nilai yang diberikan oleh guru". 
JURNAL ILMIAH

\section{Indikator Prestasi Belajar}

Menurut MuhibbinSyah

(2008)

"Pengungkapan hasil belajar meliputi segala ranah psikologis yang berubah sebagai akibat pengalaman dan proses belajar siswa”.

Di bawah ini adalah tabel yang menunjukan jenis, indikator dan cara evaluasi belajar:

Tabel 2.1 Jenis, Indikator dan Cara Evaluasi
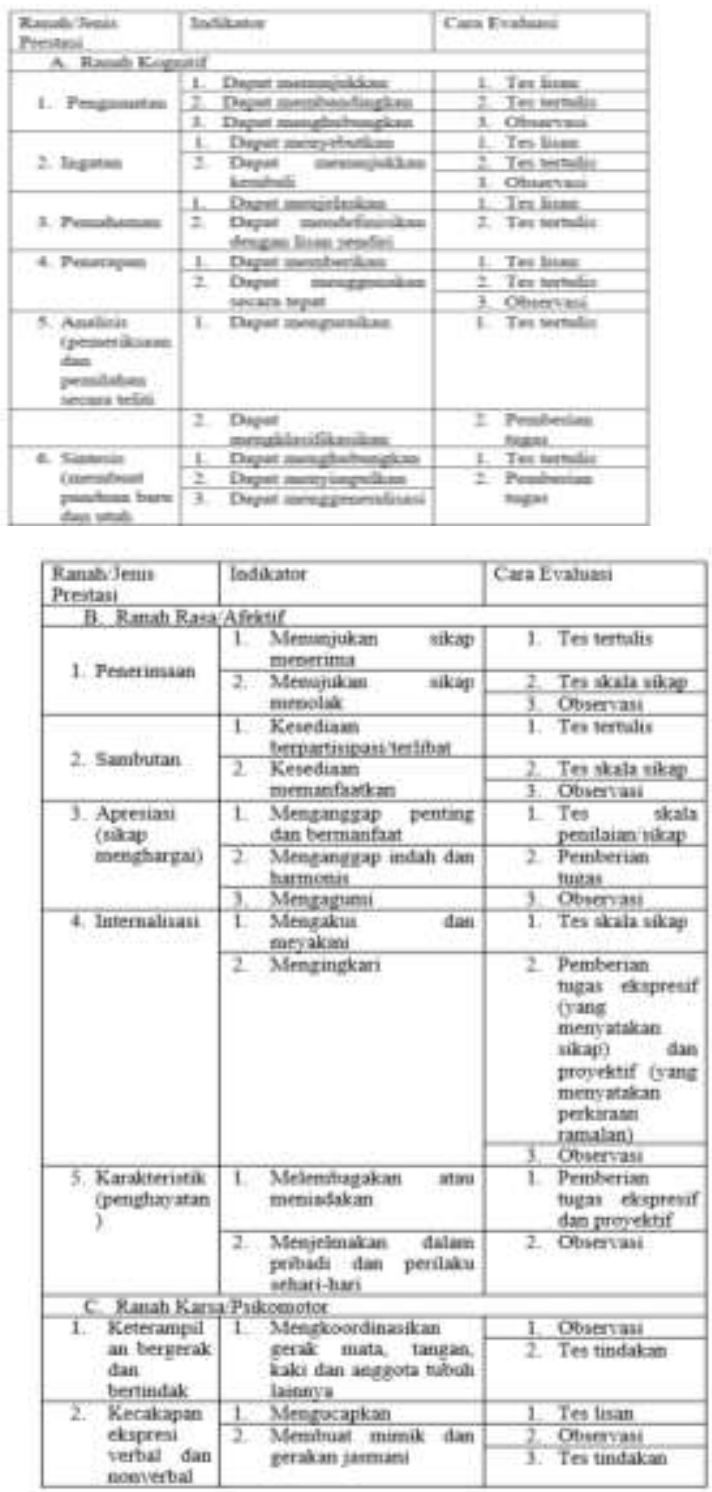

Sumber: MuhibbinSyah (2002)
3. Faktor-Faktor Yang Mempengaruhi Prestasi Belajar

Prestasi yang dicapai seorang individu merupakan hasil interaksi antara berbagai faktor yang mempengaruhi, baik dalam diri siswa maupun luar diri siswa. Adapun faktor-faktor yang mempengaruhi prestasi belajar menurut MuhibbinSyah (2008), yaitu:

a. Faktor internal (factor dari dalam diri individu)

b. Faktore ksternal (factor dari luar diri individu)

c. Faktor pendekatan belajar (approach to learning)

\section{PengertianTeknologiInformasi}

Menurut Bambang Warsita (2008) teknologi informasi adalah sarana dan prasarana (hardware, software, useware) sistem dan metode untuk memperoleh, mengirimkan.

2. ManfaatTeknologiInformasi

Menurut Bambang Warsita (2008), secaraumumadatigapemanfaatanteknologiinform asiatauinstruksionalkomputer dan internet untukpendidikan dan pembelajaran, adalah:
a. Learning about computers and the internet
b. Learning with computers and the internet

\section{Perangkat-Perangkat Teknologi Informasi}

Dalam memanfaatkan TI diperluka nperalatan/perangkat yang dapat digunakan untuk mendapatkan suatu informasi, berikut menurut Jamal M.A (2011) perangkat-perangkat teknologi informasi:

a. Komputer 
JURNAL ILMIAH

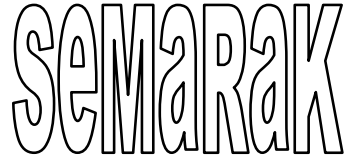

b. Laptop/Notebook

c. Deskbook

d. Smartphone/ teleponpintar

e. Flashdisk, CD, DVD, Disket, Memorycard

\section{PengertianKeluarga}

Pengertian Keluarga adalah kelompok sosial yang pertama dalam kehidupan manusia dimana seseorang belajar dan menyatakan diri sebagai manusia social dalam hubungan interaksi dengan kelompoknya (Gerungan dalam Yasin, 2016). Keluarga adalah kelompok social kecil yang umumnya terdiri dari ayah, ibu, dan anak yang mempunyai hubungan relatiftetap dan didasarkan atas ikatan darah, perkawinan, dan atau adopsi (Ahmadi dalam Yasin, 2016).

\section{Faktor-faktor dalam lingkungan keluarga}

Menurut Slameto dalam Yasin (2016) ada beberapa faktor-faktor dalam lingkungan keluarga yang akan memberikan pengaruh pada siswa antara lain:
a. Cara orang tua mendidik
b. Relasi antar anggota keluarga
c. Suasana rumah
d. Keadaan ekonomi orang tua
e. Perhatian orang tua
f. Latar belakang kebudayaan

\section{Fungsi Keluarga}

Menurut Soelaemandalam Yasin (2016) fungsi keluarga sebagai berikut:
a. Fungsi edukasi
b. Fungsi sosialisasi
c. Fungsi lindungan atau fungsi proteksi
d. Fungsi afeksi atau fungsi perasaan

\section{KerangkaBerpikir}

Berdasarkan pemikiran pada teori diatas maka dapat dilihat skema kerangka pemikiran sebagai berikut:

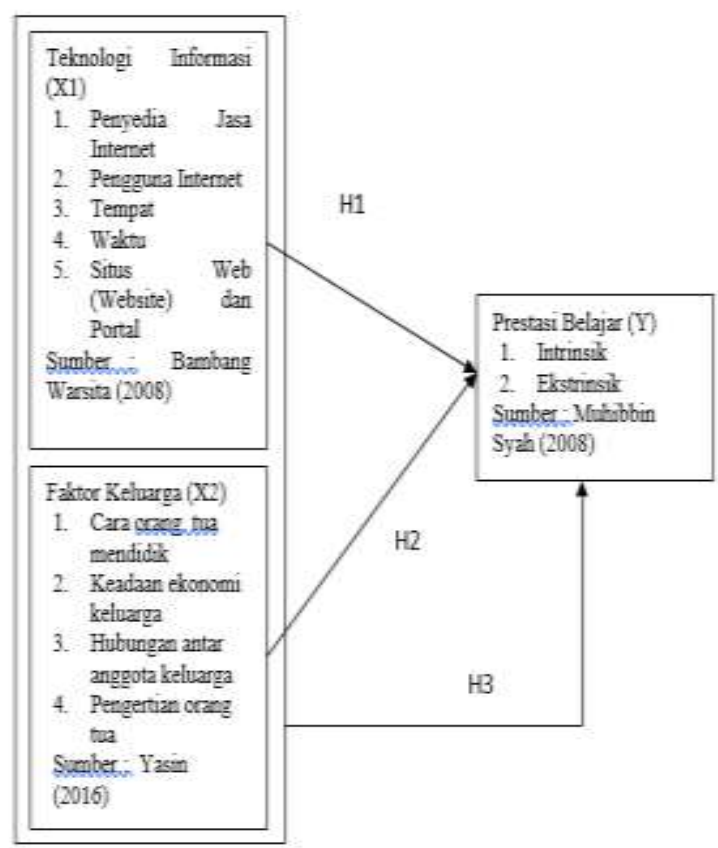

\section{Gambar 2.1 Kerangka Berpikir}

\section{METODELOGI PENELITIAN}

\section{Tempat dan Waktu Penelitian}

Dalampenelitianini, objekpenelitiannyaadalahSiswa/i SD Negeri kelas 4 Wilayah Tangerang Selatan. Penelitian ini akan dilaksanakan di instansisekolah SD Negeri kelas 4 Wilayah Tangerang Selatan yang beralamat di provinsi Banten Kota Tangerang Selatan. Untuk waktu pelaksanaan penelitian 
JURNAL ILMIAH

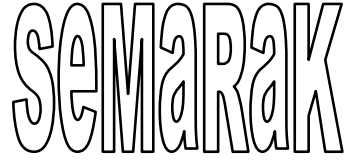

akan dimulai pada bulan Februari 2019 sampai

dengan Agustus 2019. Sedangkan rangkaian kegiatan dalam penelitian adalah pengajuan judul, uji seminar, penyebaran kuesioner, penulisan laporan akhir, dan ujian sidang.

\section{Metode Penelitian}

Pengertian metode penelitian menurut Sugiyono (2014) adalah cara ilmiah untuk mendapatkan data yang valid dengan tujuan dapat ditemukan, dibuktikan, dikembangkan suatu pengetahuan tertentu sehingga pada gilirannya dapat digunakan untuk memahami, memecahkan dan mengantisipasi masalah Metode penelitian yang digunakan adalah metode kuantitatif.

\section{Desain Penelitian}

Berdasakan rumusan dan tujuan sebelumnya, metode penelitian yang digunakan penulis adalah metode deskriptif, yaitu yang mengungkapkan gambaran masalah yang terjadi pada saat penelitian ini berlangsung. Adapun desain penelitian digambarkan sebagai berikut:

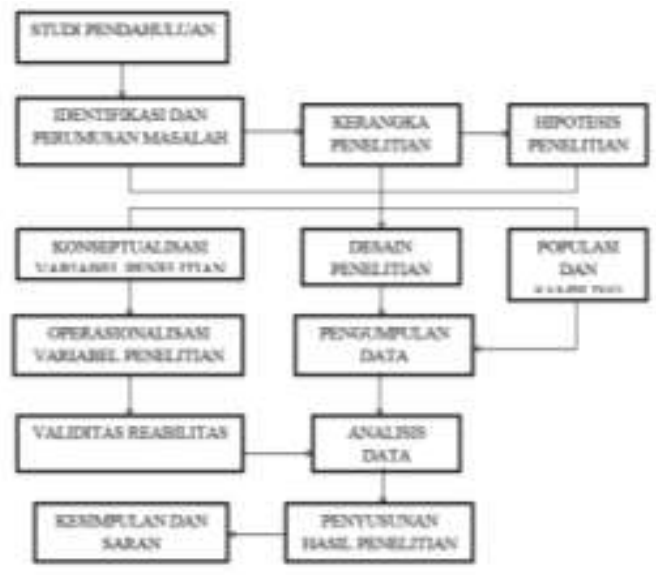

\section{TeknikPengumpulan Data}

Tabel 3.2

Skala Likert

\begin{tabular}{|c|c|}
\hline Tipe & Skor \\
\hline SS: Sangat Setuju & 5 \\
\hline S: Setuju & 4 \\
\hline R : Ragu-ragu & 3 \\
\hline TS: Tidak Setuju & 2 \\
\hline $\begin{array}{c}\text { STS:Sangat Tidak } \\
\text { Setuju }\end{array}$ & 1 \\
\hline
\end{tabular}

Tabel 3.3

Rentang Interval Skor

\begin{tabular}{|c|c|c|c|}
\hline Jawaban & $\begin{array}{c}\text { Bobo } \\
\mathbf{t}\end{array}$ & $\begin{array}{c}\text { Rentang } \\
\text { Interval } \\
\text { Skor }\end{array}$ & $\begin{array}{c}\text { Kategor } \\
\mathbf{i}\end{array}$ \\
\hline SangatBaik & 5 & $\begin{array}{c}4,20 \geq \\
5,00\end{array}$ & SB \\
\hline Baik & 4 & $\begin{array}{c}3,40 \geq \\
4,20\end{array}$ & B \\
\hline KurangBaik & 3 & $\begin{array}{c}2,60 \geq \\
3,40\end{array}$ & KB \\
\hline TidakBaik & 2 & $\begin{array}{c}1.80 \geq \\
2,60\end{array}$ & TB \\
\hline SangatTidakBaik & 1 & $1,00 \geq$ & STB \\
\hline
\end{tabular}

Sumber: Sugiyono (2016)

\section{E. Hasil Penelitian}

\section{Uji Validitas}

a) Uji Validitas Variabel Teknologi Informasi $\left(\mathbf{X}_{1}\right)$ 
JURNAL ILMIAH

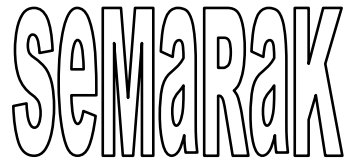

P-ISSN 2615-6849, E-ISSN 2622-3686

Guna mengetahui hasil analisis uji validitas dari variable Teknologi Informasi $\left(\mathrm{X}_{1}\right)$ dengan sampel berjumlah 128 dengan jumlah pernyataan sebanyak 10 pernyataan sebagai berikut:

Tabel 4.8

\section{Hasil Uji Validitas Teknologi}

\section{Informasi $\left(\mathbf{X}_{1}\right)$}

\begin{tabular}{|c|c|c|c|}
\hline No & $\mathbf{R}_{\text {Hitung }}$ & $\mathbf{R}_{\text {Tabel }}$ & Ket \\
\hline 1 & 0.482 & 0.1736 & Valid \\
\hline 2 & 0.330 & 0.1736 & Valid \\
\hline 3 & 0.471 & 0.1736 & Valid \\
\hline 4 & 0.492 & 0.1736 & Valid \\
\hline 5 & 0.730 & 0.1736 & Valid \\
\hline 6 & 0.556 & 0.1736 & Valid \\
\hline 7 & 0.703 & 0.1736 & Valid \\
\hline 8 & 0.687 & 0.1736 & Valid \\
\hline 9 & 0.714 & 0.1736 & Valid \\
\hline 10 & 0.492 & 0.1736 & Valid \\
\hline
\end{tabular}

Sumber : Data Olahan

Kuesioner 2019

Berdasarkan tabel diatas dapat dilihat bahwa untuk masing-masing pernyataan pada variabel TeknologiInformasi $\left(\mathrm{X}_{1}\right)$ seluruh item terbukti valid, karena nilai $r_{\text {hitung }}$ yang dihasilkan lebih besar dari pada nilai $r_{\text {tabel }}$ yang ada untuk $n=128$ yaitu 0,1736 .

b) Uji Validitas VariabelFaktorKeluarga $\left(\mathrm{X}_{2}\right)$

Hasil uji validitas instrumen variabel FaktorKeluarga $\left(\mathrm{X}_{2}\right)$ yang terdiri dari 10 instrumen pernyataan adalah :

\section{Tabel 4.9}

\section{Hasil Uji Validitas FaktorKeluarga $\left(\mathbf{X}_{2}\right)$}

\begin{tabular}{|c|l|c|c|}
\hline No & $\mathbf{R}_{\text {Hitung }}$ & $\mathbf{R}_{\text {Tabel }}$ & Ket \\
\hline 1 & 0.525 & 0.1736 & Valid \\
\hline 2 & 0.466 & 0.1736 & Valid \\
\hline 3 & 0.224 & 0.1736 & Valid \\
\hline
\end{tabular}

\begin{tabular}{|c|l|l|l|}
\hline No & $\mathbf{R}_{\text {Hitung }}$ & $\mathbf{R}_{\text {Tabel }}$ & Ket \\
\hline 4 & 0.529 & 0.1736 & Valid \\
\hline 5 & 0.592 & 0.1736 & Valid \\
\hline 6 & 0.452 & 0.1736 & Valid \\
\hline 7 & 0.619 & 0.1736 & Valid \\
\hline 8 & 0.504 & 0.1736 & Valid \\
\hline 9 & 0.622 & 0.1736 & Valid \\
\hline 10 & 0.690 & 0.1736 & Valid \\
\hline
\end{tabular}

Sumber : Data Olahan Kuesioner 2019

Berdasarkan tabel diatas dapat dilihat bahwa untuk masing-masing pernyataan pada variabel Faktor Keluarga $\left(\mathrm{X}_{2}\right)$ seluruh item terbukti valid, karena nilai $r_{\text {hitung }}$ yang dihasilkan lebih besar dari pada nilai $r_{\text {tabel }}$ yang ada untuk $n=128$ yaitu 0,1736 .

c) Uji Validitas Variabel PrestasiBelajar (Y)

Hasil uji validitas instrumen variabel PrestasiBelajar (Y)yang terdiri dari 10 instrumen pernyataan adalah :

Tabel 4.10

\section{Hasil Uji Validitas PrestasiBelajar (Y)}

\begin{tabular}{|c|l|c|c|}
\hline $\mathbf{N}$ & \multicolumn{1}{|c|}{$\mathbf{R}_{\text {Hitung }}$} & $\mathbf{R}_{\text {Tabel }}$ & Ket \\
\hline $\mathbf{1}$ & \multicolumn{1}{|c|}{} & 0.1736 & Valid \\
\hline 2 & 0.702 & 0.1736 & Valid \\
\hline 3 & 0.515 & 0.1736 & Valid \\
\hline 4 & 0.621 & 0.1736 & Valid \\
\hline 5 & 0.588 & 0.1736 & Valid \\
\hline 6 & 0.558 & 0.1736 & Valid \\
\hline 7 & 0.746 & 0.1736 & Valid \\
\hline 8 & 0.580 & 0.1736 & Valid \\
\hline 9 & 0.731 & 0.1736 & Valid \\
\hline 10 & 0.512 & 0.1736 & Valid \\
\hline
\end{tabular}

Sumber : Data Olahan Kuesioner 2019

Berdasarkan tabel diatas dapat dilihat bahwa untuk masing-masing pernyataan pada variabelPrestasiBelajar(Y) seluruh item terbukti valid, karena nilai $r_{\text {hitung }}$ yang 
JURNAL ILMIAH

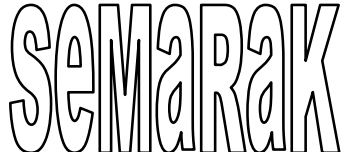

dihasilkan lebih besar dari pada nilai $r$ tabel yang ada untuk $n=128$ yaitu 0,1736 .

\section{Uji Reliabilitas}

a. Uji

ReliabilitasVariabel

TeknologiInformasi $\left(\mathbf{X}_{1}\right)$

Tabel 4.11

Uji Reliabilitas Variabel TeknologiInformasi $\left(\mathrm{X}_{1}\right)$

Reliability Statistics

\begin{tabular}{|l|l|}
\hline Cronbach's Alpha & N of Items \\
\hline
\end{tabular}

.767

10

Sumber : Data Hasil olahan SPSS 21

b. Uji Reliabilitas Variabel Faktor Keluarga $\left(\mathbf{X}_{2}\right)$

Tabel 4.12

Uji Reliabilitas Variabel FaktorKeluarga $\left(\mathbf{X}_{2}\right)$

Reliability Statistics

\begin{tabular}{ll} 
Cronbach's Alpha $\mathrm{N}$ of Items \\
\hline
\end{tabular}

.740

10

Sumber :Datahasilolahan SPSS 21

c. Uji ReliabilitasVariabel PrestasiBelajar (Y)

Tabel 4.13

Uji Reliabilitas Variabel Prestasi Belajar (Y)

Reliability Statistics

\begin{tabular}{|l|l}
\hline Cronbach's Alpha & N of Items \\
\hline
\end{tabular}

.814

10

Sumber : Data hasilolahan SPSS 21

3. Uji Asumsi Klasik

a. Uji Normalitas metode pengujian, yaitu :

1) Uji Normalitas Menggunakan Analisis Grafik

Hasil Output uji normalitas grafik PPlot adalah sebagai berikut:

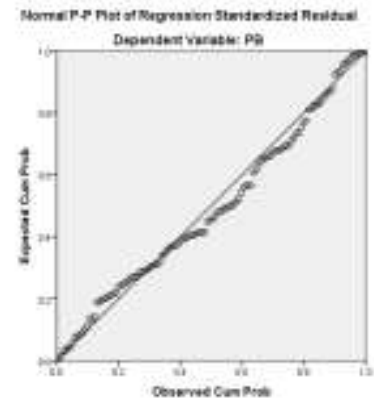

Sumber : Data Hasil Olahan SPSS 21

Gambar 4.2

Hasil OutputNormalitasMetode P-Plot

Hasil Output uji normalitas grafik Histogram adalah sebagai berikut:

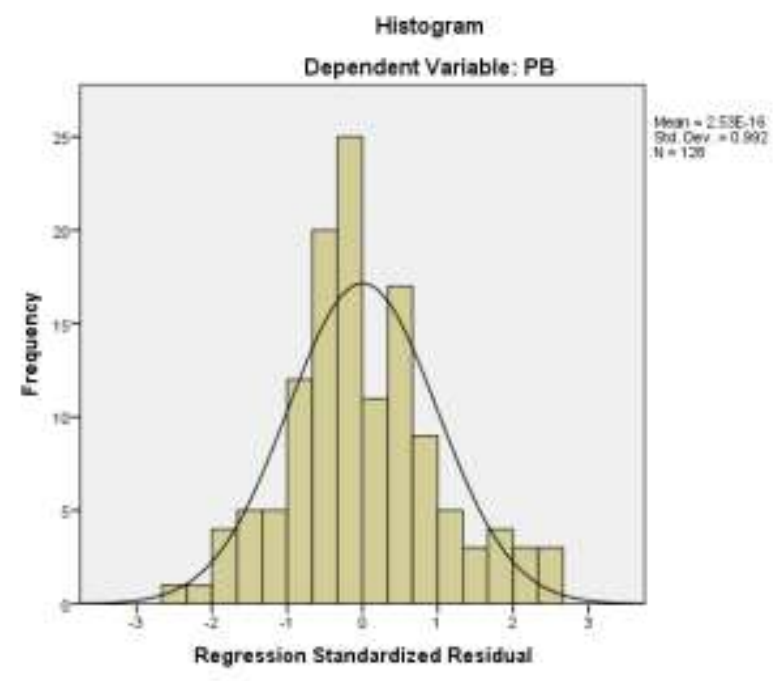

Gambar 4.3

\section{Hasil Output Normalitas Histogram}

2) Uji Normalitas Menggunakan Analisis Statistik 
JURNAL ILMIAH

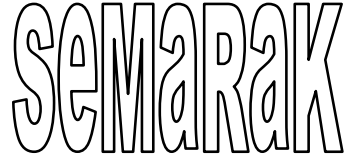

Hasil Output

Kolmogorov-Smirnov adalah sebagai berikut:

Tabel 4.14

Hasil Output Uji Normalitas Kolmogorov-Smirnov

One-Sample Kolmogorov-Smirnov Test

\begin{tabular}{|ll|r|}
\hline & & $\begin{array}{r}\text { Unstandardized } \\
\text { Residual }\end{array}$ \\
\hline $\mathrm{N}$ & Mean & 128 \\
Normal & Std. & .0000000 \\
Parameters & abb & Deviation \\
Most & Absolute & .55616887 \\
Extreme & Positive & .073 \\
Differences & Negative & -.062 \\
Kolmogorov-Smirnov Z & .821 \\
Asymp. Sig. (2-tailed) & .510 \\
\hline
\end{tabular}

a. Test distribution is Normal.

b. Calculated from data.

Dari hasil uji Normalitas dengan metode Kolmogorov-Smirnov di atas Sig 0,05 untuk besarnya nilai Test Statistic

Kolmogorov-Smirnov diperoleh 0,821 dan nilaiSig 0,510 .

Nilai signifikansi lebih besar dari 0,05 yang berarti data residual berdistribusi normal.

\section{b. Uji Heterokedastisitas}

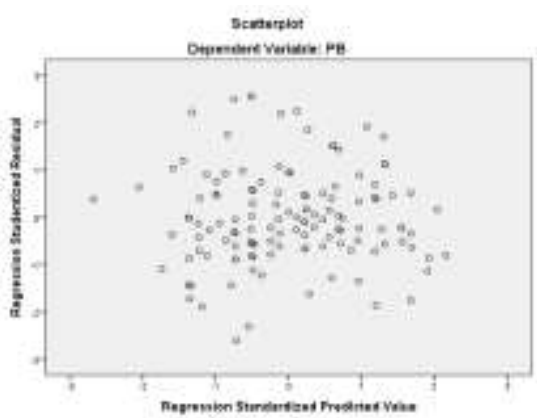

Sumber : Data Hasil Olahan SPSS 21

\section{Hasil OutputHeterokedasisitasScatterplot \\ c. Uji Multikolinieritas}

Tabel 4.15

\section{Hasil Output SPSS 21 PengujianMultikolinieritas}

Coefficients

\begin{tabular}{|c|c|c|c|c|c|c|c|}
\hline \multirow[t]{2}{*}{ Model } & \multicolumn{2}{|c|}{$\begin{array}{l}\text { Unstandar } \\
\text { dized } \\
\text { Coefficien } \\
\text { ts }\end{array}$} & \multirow{2}{*}{$\begin{array}{l}\text { Stand } \\
\text { ardize } \\
d \\
\text { Coeffi } \\
\text { cients } \\
\text { Beta }\end{array}$} & \multirow[t]{2}{*}{$\mathrm{t}$} & \multirow[t]{2}{*}{$\begin{array}{l}\mathrm{Si} \\
\text { g. }\end{array}$} & \multicolumn{2}{|c|}{$\begin{array}{l}\text { Collinea } \\
\text { rity } \\
\text { Statistic } \\
\text { s }\end{array}$} \\
\hline & B & $\begin{array}{l}\text { Std. } \\
\text { Error }\end{array}$ & & & & $\begin{array}{c}\text { Tole } \\
\text { ranc } \\
\mathrm{e}\end{array}$ & $\begin{array}{l}\text { V } \\
\text { IF }\end{array}$ \\
\hline (Con & 8.2 & 2.91 & & 2.8 & .0 & & \\
\hline stant & 41 & 8 & & 24 & 06 & & \\
\hline & .39 & .077. & .390 & 5.0 & .0 & .719 & 1. \\
\hline TI & 1 & & & 67 & 00 & & 3 \\
\hline & .41 & .082 & .392 & 5.1 & .0 & .719 & 1. \\
\hline FKel & 7 & & & 00 & 00 & & 3 \\
\hline & & & & & & & 2 \\
\hline
\end{tabular}

Sumber : Data Hasil Olahan SPSS 21

d. Uji Regresi Linear

a. Uji Regresi Linear Sederhana

TeknologiInformasi $\quad\left(\mathrm{X}_{1}\right) \quad$ Terhadap

PrestasiBelajar (Y)

Tabel 4.16

OutputTeknologiInformasi $\left(\mathrm{X}_{1}\right)$ Terhadap

PrestasiBelajar (Y)

Coefficients $^{\text {a }}$

\begin{tabular}{|l|c|c|c|c|c|}
\hline Model & \multicolumn{2}{|c|}{$\begin{array}{c}\text { Unstandardi } \\
\text { zed } \\
\text { Coefficients }\end{array}$} & $\begin{array}{c}\text { Standar } \\
\text { dized } \\
\text { Coeffic } \\
\text { ients }\end{array}$ & $\mathrm{T}$ & Sig \\
& $\mathrm{B}$ & $\begin{array}{c}\text { Std. } \\
\text { Error }\end{array}$ & Beta & \\
\hline
\end{tabular}




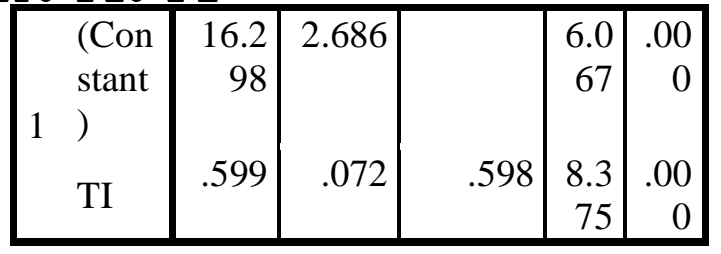

a. Dependent Variable: PB

Sumber : Data Olahan SPSS 21

Berdasarkan tabel Output di atas dapat dijelaskan bahwa, persamaan regresi linear sederhana $\mathrm{Y}=\mathrm{a}+\mathrm{b}(\mathrm{x})$ adalah $\mathrm{Y}=$ $16,298+0,599\left(\mathrm{x}_{1}\right)$. Persamaan regresi ini dapat disimpulkan bahwa, terdapat pengaruh positif antara TeknologiInformasi $\quad\left(\mathrm{X}_{1}\right) \quad$ Terhadap PrestasiBelajar (Y).

b. Analisa Regresi Linear Sederhana FaktorKeluarga $\quad\left(\mathrm{X}_{2}\right) \quad$ Terhadap Prestasibelajar (Y)

Tabel 4.17

Output Regresi Linear Sederhana

FaktorBelajar $\left(\mathrm{X}_{2}\right)$ Terhadap

PrestasiBelajar (Y)

Coefficients $^{\mathbf{a}}$

\begin{tabular}{|c|c|c|c|c|c|}
\hline \multirow[t]{2}{*}{ Model } & \multicolumn{2}{|c|}{$\begin{array}{l}\text { Unstandardi } \\
\text { zed } \\
\text { Coefficients }\end{array}$} & $\begin{array}{l}\text { Standa } \\
\text { rdized } \\
\text { Coeffi }\end{array}$ & \multirow[t]{2}{*}{$\mathrm{t}$} & \multirow[t]{2}{*}{$\begin{array}{l}\mathrm{S} \\
\mathrm{i} \\
\mathrm{g}\end{array}$} \\
\hline & B & $\begin{array}{l}\text { Std. } \\
\text { Error }\end{array}$ & Beta & & \\
\hline \multirow{6}{*}{$\begin{array}{l}\text { (Con } \\
\text { stant } \\
\left.{ }_{1}\right) \\
\text { FKel }\end{array}$} & 14.4 & 2.897 & & 4.9 & \\
\hline & 45 & & & 87 & 0 \\
\hline & & & & & 0 \\
\hline & .637 & .076 & .599 & 8.4 & \\
\hline & & & & 02 & 0 \\
\hline & & & & & 0 \\
\hline
\end{tabular}

a. Dependent Variable: PB

Sumber : Data Olahan SPSS 21
Berdasarkan tabel Output di atas dapat dijelaskan bahwa, persamaan regresi linear sederhana $\mathrm{Y}=\mathrm{a}+\mathrm{b}(\mathrm{x})$ adalah $\mathrm{Y}=$ $14,445+0,637\left(\mathrm{x}_{2}\right)$. Persaman regresi ini dapat disimpulkan bahwa, terdapat pengaruh positif antara FaktorKeluarga $\left(\mathrm{X}_{2}\right)$ Terhadap PrestasiBelajar (Y).

c. Analisa Regresi Linear Berganda TeknologiInformasi $\quad\left(\mathrm{X}_{1}\right)$ dan FaktorKeluarga $\quad\left(\mathrm{X}_{2}\right) \quad$ Terhadap PrestasiBelajar (Y)

Tabel 4.18

Output Regresi Linear Berganda

TeknologiInformasi $\left(X_{1}\right)$ dan FaktorKeluarga $\left(X_{2}\right)$

TerhadapPrestasiBelajar (Y)

Coefficients $^{\mathrm{a}}$

\begin{tabular}{|c|c|c|c|c|c|}
\hline \multirow[t]{2}{*}{ Model } & \multicolumn{2}{|c|}{$\begin{array}{c}\text { Unstandar } \\
\text { dized } \\
\text { Coefficient } \\
\text { s } \\
\end{array}$} & $\begin{array}{l}\text { Standa } \\
\text { rdized } \\
\text { Coeffi } \\
\text { cients } \\
\end{array}$ & $\mathrm{t}$ & Sig. \\
\hline & $\mathrm{B}$ & $\begin{array}{l}\text { Std. } \\
\text { Error }\end{array}$ & Beta & & \\
\hline $\begin{array}{l}\text { (Con } \\
\text { stant } \\
\text { ) }\end{array}$ & $\begin{array}{r}8.24 \\
1\end{array}$ & $\begin{array}{r}2.91 \\
8\end{array}$ & & $\begin{array}{r}2.8 \\
24\end{array}$ & .006 \\
\hline${ }^{1} \mathrm{TI}$ & .391 & .077 & .390 & $\begin{array}{r}5.0 \\
67\end{array}$ & .000 \\
\hline FKel & .417 & .082 & .392 & $\begin{array}{r}5.1 \\
00\end{array}$ & .000 \\
\hline
\end{tabular}

a. Dependent Variable: PB

Sumber : Data Olahan SPSS 21

Berdasarkan tabel Output di atas dapat dijelaskan bahwa, persamaan regresi linear berganda $\mathrm{Y}=\mathrm{a}+\mathrm{b}_{1} \mathrm{x}_{1}+\mathrm{b}_{2} \mathrm{x}_{2}$ adalah $\mathrm{Y}=8,241+0,391\left(\mathrm{x}_{1}\right)+0,417\left(\mathrm{x}_{2}\right)$. Persamaan regresi ini dapat disimpulkan bahwa, terdapat pengaruh positif antara 
JURNAL ILMIAH

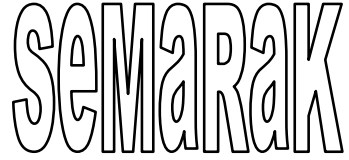

P-ISSN 2615-6849, E-ISSN 2622-3686

Jurnal Semarak,Vol. 3,No.1, Februari 2020, Hal (60- 74)

@Prodi Manajemen Fakultas Ekonomi Universitas Pamulang

$$
\begin{aligned}
& \text { TeknologiInformasi }\left(\mathrm{X}_{1}\right) \\
& \text { FaktorKeluarga } \\
& \text { TerhadapPrestasiBelajar }(\mathrm{Y}) .
\end{aligned}
$$

F. Uji Hipotesis

1) Uji Parsial (Uji t)

a) Uji Hipotesis Parsial TeknologiInformas

$\left(\mathbf{X}_{1}\right)$ Terhadap PrestasiBelajar (Y)

Tabel 4.19

Output Uji HipotesisTeknologiInformasi $\left(\mathbf{X}_{1}\right)$

\begin{tabular}{|c|c|c|c|c|c|}
\hline \multirow[t]{2}{*}{ Model } & \multicolumn{2}{|c|}{$\begin{array}{l}\text { Unstandardize } \\
\text { d Coefficients }\end{array}$} & $\begin{array}{c}\text { Standardized } \\
\text { Coefficients }\end{array}$ & \multirow[t]{2}{*}{$\mathrm{T}$} & \multirow[t]{2}{*}{ Sig } \\
\hline & B & $\begin{array}{l}\text { Std. } \\
\text { Error }\end{array}$ & Beta & & \\
\hline \multirow{4}{*}{$\begin{array}{c}1^{(\text {Cont })} \\
\text { TI }\end{array}$} & 16. & 2.686 & & 6.0 & .00 \\
\hline & 29 & & & 67 & 0 \\
\hline & .59 & .072 & .598 & 8.3 & .00 \\
\hline & 9 & & & 75 & 0 \\
\hline
\end{tabular}

TerhadapPrestasiBelajar (Y)

Coefficients $^{\mathbf{a}}$

a. Dependent Variable: PB

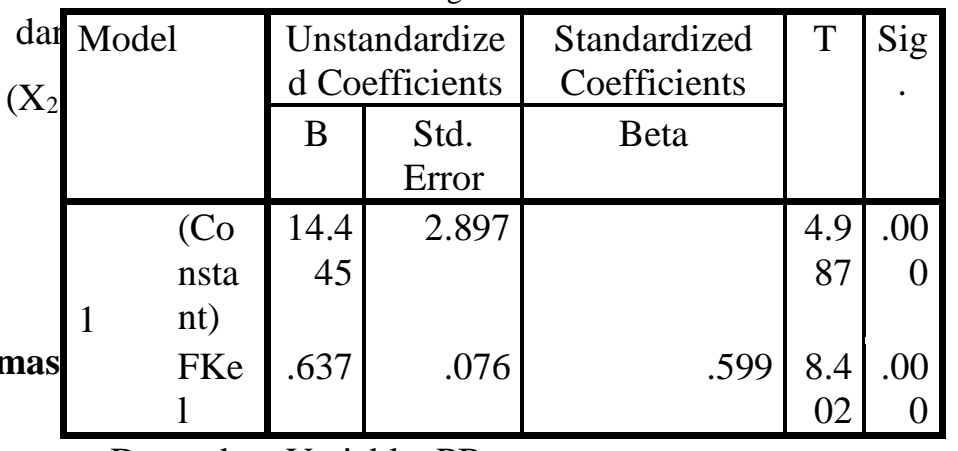

Sumber : Data Olahan SPSS 21

a. Dependent Variable: PB

Sumber : Data Olahan SPSS 21

Nilai $\mathrm{t}$ hitungvariabelFaktorKeluarga $\left(\mathrm{X}_{2}\right)$ terhadapPrestasiBelajar $(\mathrm{Y})$ sebesar $\mathrm{t}$ hitung 8,402>t tabel1,65704atau nilaiSig $0,000<$ 0,05 maka $\mathrm{Ho}_{2}$ di tolak dan artinyaterdapatpengaruhpositif dan signifikanantaraFaktorKeluarga $\quad\left(\mathrm{X}_{2}\right)$ terhadapPrestasiBelajar (Y).

2) Uji HipotesisSimultan (Uji F)

Tabel 4.21

OutputUji F ( $\left.\mathbf{X}_{1}\right)$ dan $\left(\mathbf{X}_{2}\right)$ Terhadap (Y)

Nilai

hitungVariabelTeknologiInformasi

terhadapPrestasiBelajar (Y) sebesar $\mathrm{t}$ hitung

$8,375>\mathrm{t}_{\text {tabel }} 1,65704$ ataunilaiSig $0,000<0,05$

\begin{tabular}{r|l|r|r|r|c|c|}
\cline { 2 - 7 } \multicolumn{1}{c|}{$\left(\mathrm{X}_{1}\right)$} & Model & $\begin{array}{c}\text { Sum of } \\
\text { Squares }\end{array}$ & $\mathrm{df}$ & $\begin{array}{c}\text { Mean } \\
\text { Square }\end{array}$ & $\mathrm{F}$ & Sig. \\
\cline { 3 - 8 } hitung & Regression & 1414.384 & 2 & 707.192 & 55.040 & $.000^{\mathrm{b}}$ \\
0,05 & Residual & 1606.085 & 125 & 12.849 & & \\
\cline { 3 - 8 } & Total & 3020.469 & 127 & & & \\
\hline
\end{tabular}

maka $\mathrm{Ho}_{1} \quad \mathrm{di}$ tolak

dan a. Dependent Variable: PB

artinyaterdapatpengaruhpositif

dan

b. Predictors: (Constant), FKel, TI

signifikanantaraTeknologiInformasi $\quad\left(\mathrm{X}_{1}\right)$

Sumber : Data Olahan SPSS 21

terhadapPrestasiBelajar (Y).

b) Uji Hipotesis ParsialFaktorKeluarga $\left(\mathbf{X}_{2}\right)$

Terhadap PrestasiBelajar(Y)

Tabel 4.20

Output Uji HipotesisFaktorKeluarga

$\left(\mathbf{X}_{2}\right)$ TerhadapPrestasi Belajar (Y)

Coefficients $^{\mathrm{a}}$

Melihat tabel Output di atas dapat dijelaskan bahwa, $\mathrm{F}_{\text {hitung }} 55,040>\mathrm{F}$ tabel 3,07 atau probabilitas $\mathrm{Sig} 0,000<0,05$ maka $\mathrm{Ho}_{3}$ di tolak dan $\mathrm{Ha}_{3}$ di terimaartinyasignifikan dengan demikian hipotesis yang diajukan menetapkanterdapatpengaruhpositif dan signifikan secara bersama-sama antara TeknologiInformasi $\left(\mathrm{X}_{1}\right)$ dan FaktorBelajar 
JURNAL ILMIAH

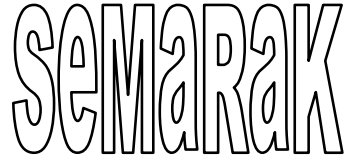

P-ISSN 2615-6849, E-ISSN 2622-3686

$\left(\mathrm{X}_{2}\right)$ Terhadap PrestasiBelajar (Y)Siswa/i SD

Jurnal Semarak,Vol. 3,No.1, Februari 2020, Hal (60- 74)

@ Prodi Manajemen Fakultas Ekonomi Universitas Pamulang

Negeri kelas 4 Wilayah Tangerang Selatan.

\section{3) KoefisienDeterminasi}

Tabel 4.22

OutputKoefisienDeterminasiTeknologi

Informasi $\left(\mathbf{X}_{1}\right)$ Terhadap Prestasi Belajar

(Y)

\begin{tabular}{|c|c|c|c|c|}
\hline \multicolumn{5}{|c|}{ Model Summary } \\
\hline Model & $\mathrm{R}$ & $\begin{array}{c}\mathrm{R} \\
\text { Square }\end{array}$ & $\begin{array}{l}\text { Adjusted } \\
\text { R Square }\end{array}$ & $\begin{array}{l}\text { Std. Error } \\
\text { of the } \\
\text { Estimate }\end{array}$ \\
\hline 1 & $.598^{a}$ & .358 & .353 & 3.924 \\
\hline
\end{tabular}

a. Predictors: (Constant), TI

Sumber : Data Olahan SPSS 21

Nilai korelasi $\mathrm{R}=0,598$ berada pada rentang $0,400-0,599$ dengan tingkat hubungan sedang, artinya TeknologiInformasi $\left(\mathrm{X}_{1}\right)$ memiliki tingkat hubungan sedang terhadap PrestasiBelajar (Y).

a) Koefisien Determinasi FaktorKeluarga $\left(X_{2}\right)$ Terhadap PrestasiBelajar(Y)

\section{Tabel 4.23}

\section{Output Koefisien Determinasi Faktor}

Keluarga $\left(\mathbf{X}_{2}\right)$ Terhadap Prestasi Belajar

(Y)

\begin{tabular}{|l|c|c|c|c|}
\hline Model & $\mathrm{R}$ & $\begin{array}{c}\mathrm{R} \\
\text { Square }\end{array}$ & $\begin{array}{c}\text { Adjusted } \\
\mathrm{R} \\
\text { Square }\end{array}$ & $\begin{array}{c}\text { Std. } \\
\text { Error of } \\
\text { the } \\
\text { Estimate }\end{array}$ \\
\hline 1 & $.599^{\mathrm{a}}$ & .359 & .354 & 3.920 \\
\hline
\end{tabular}

a. Predictors: (Constant), FKel

Sumber : Data Olahan SPSS 21

Nilai korelasi $\mathrm{R}=0,599$ berada pada rentang 0,400-0,599 dengan tingkat hubungan sedang, artinya FaktorKeluarga $\left(\mathrm{X}_{2}\right)$ memiliki tingkat hubungan sedang terhadap PrestasiBelajar (Y).

b) Koefisien Determinasi $\left(\mathrm{X}_{1}\right)$ dan $\left(\mathrm{X}_{2}\right)$ Terhadap (Y)

Tabel 4.24

OutputKoefisien Determinasi $\left(\mathrm{X}_{1}\right)$ dan $\left(\mathbf{X}_{2}\right)$ Terhadap (Y)

Model Summary ${ }^{\mathrm{b}}$

\begin{tabular}{|l|c|c|c|c|c|}
\hline $\begin{array}{l}\text { Mode } \\
1\end{array}$ & $\mathrm{R}$ & $\begin{array}{c}\mathrm{R} \\
\text { Squar } \\
\mathrm{e}\end{array}$ & $\begin{array}{c}\text { Adjuste } \\
\mathrm{d} \mathrm{R} \\
\text { Square }\end{array}$ & $\begin{array}{c}\text { Std. } \\
\text { Error } \\
\text { of the } \\
\text { Estimat } \\
\mathrm{e}\end{array}$ & $\begin{array}{c}\text { Durbin } \\
- \\
\text { Watso } \\
\mathrm{n}\end{array}$ \\
\hline 1 & $\begin{array}{r}.684 \\
\mathrm{a}\end{array}$ & .468 & .460 & 3.585 & 1.706 \\
\hline
\end{tabular}

a. Predictors: (Constant), FKel, TI

b. Dependent Variable: PB

Sumber : Data Olahan SPSS 21 Tahun 2019

Nilai korelasi $\mathrm{R}=0,684$ berada pada rentang 0,600 - 0,799 dengan tingkat hubungan kuat, artinya TeknologiInformasi $\left(\mathrm{X}_{1}\right)$ dan FaktorKeluarga $\left(\mathrm{X}_{2}\right)$ memiliki tingkat hubungan kuat terhadap PrestasiBelajar (Y).

\section{G. KESIMPULAN}

1. Pengaruh Teknologi Informasi $\left(X_{1}\right)$ Terhadap Prestasi Belajar (Y)

Berdasarkan hasil penelitian menunjukkan bahwa, Terdapatpengaruhpositif dan signifikan secara parsial antara Teknologi Informasi $\left(\mathrm{X}_{1}\right)$ terhadapPrestasi Belajar $(\mathrm{Y})$ pada Siswa/i SD Negeri kelas 4 Wilayah Tangerang Selatan. Hal ini dibuktikan dengan persamaan regresi linear sederhana $\mathrm{Y}=\mathrm{a}+\mathrm{b}(\mathrm{X})$ adalah $\mathrm{Y}=$ $16,298+0,599\left(\mathrm{x}_{1}\right) \cdot$ jika terdapat kenaikan satusatuan pada variabel Teknologi Informasi $\left(\mathrm{X}_{1}\right)$ 
Jurnal Semarak,Vol. 3,No.1, Februari 2020, Hal (60- 74)

@Prodi Manajemen Fakultas Ekonomi Universitas Pamulang

maka nilai Prestasi Belajar (Y) akan bertambah sebesar 0,599 satuan.

\section{PengaruhFaktorKeluarga $\left(\mathbf{X}_{2}\right)$ Terhadap} Prestasi Belajar (Y)

Berdasarkan hasil penelitian menunjukkan bahwa, Terdapatpengaruhpositif dan signifikan secara secara parsial antara FaktorKeluarga $\left(\mathrm{X}_{2}\right)$ terhadapPrestasi Belajar (Y) pada Siswa/i SD Negeri kelas 4 Wilayah Tangerang Selatan. Hal ini dibuktikan dengan persamaan regesi linear sederhana $\mathrm{Y}=\mathrm{a}+\mathrm{b}(\mathrm{x})$ adalah $\mathrm{Y}=14,445+0,637\left(\mathrm{x}_{2}\right)$. jika terdapat kenaikan satu-satuan pada variabel FaktorKeluarga $\left(\mathrm{X}_{2}\right)$ maka nilai Prestasi Belajar (Y) akan bertambah sebesar 0,637 satuan .

\section{Pengaruh Teknologi Informasi $\left(\mathbf{X}_{1}\right)$, FaktorKeluarga $\left(\mathbf{X}_{2}\right)$ Terhadap Prestasi Belajar (Y)}

Berdasarkan hasil penelitian menunjukkan bahwa, Terdapatpengaruhpositif dan signifikan secara simultan antara Teknologi Informasi $\left(\mathrm{X}_{1}\right)$ danFaktorKeluarga $\left(\mathrm{X}_{2}\right)$ terhadapPrestasi Belajar (Y) pada Siswa/i SD Negeri kelas 4 Wilayah Tangerang Selatan. Hal ini dibuktikan dengan Berdasarkan tabel output di atas dapat dijelaskan bahwa, persamaan regresi linear berganda $\mathrm{Y}=\mathrm{a}+\mathrm{b}_{1} \mathrm{x}_{1}+\mathrm{b}_{2} \mathrm{x}_{2}$ adalah $\mathrm{Y}=8,241+0,391\left(\mathrm{x}_{1}\right)+0,417\left(\mathrm{x}_{2}\right)$. Persamaan regresi ini dapat disimpulkan bahwa, terdapat pengaruh positif antara Teknologi Informasi $\left(\mathrm{X}_{1}\right)$ dan FaktorKeluarga $\left(\mathrm{X}_{2}\right)$ Terhadap Prestasi Belajar (Y). Konstanta $a=8,241$ menunjukkan bahwa, nilai Prestasi Belajar (Y) saat ini diasumsikan bernilai 8,241 satuan dengan asumsi variabel Teknologi Informasi $\left(\mathrm{X}_{1}\right)$ danFaktorKeluarga $\left(\mathrm{X}_{2}\right)$ bernilai tetap. Konstanta $\mathrm{b}_{1} \mathrm{x}_{1}=0,391$ menunjukkan bahwa, jika terdapat kenaikan satu-satuan pada variabel Teknologi Informasi $\left(\mathrm{X}_{1}\right)$ maka nilai Prestasi Belajar (Y) akan bertambah sebesar 0,391 satuan. Konstanta $\mathrm{b}_{2} \mathrm{x}_{2}=0,417$ menunjukkan bahwa, jika terdapat kenaikan satu-satuan pada variabel Lingkungan Kerja $\left(\mathrm{X}_{2}\right)$ maka nilai Prestasi Belajar (Y) akan bertambah sebesar 0,417 satuan.

\section{H. SARAN}

Saran-saran yang dapat peneliti berikan sebagai masukan dalam peningkatan Teknologi Informasi, FaktorKeluarga, beban kerja dan Prestasi Belajar adalah sebagai berikut :

1. Variabel TeknologiInformasi $\left(\mathrm{X}_{1}\right)$ yang harus ditingkatkan adalah pada instrumen no 3 dan 6 yang mendapatkan skor rata-rata terendah sebesar 3,61. Pada instrumen ini agarsekolahdapatmemberikanpenjelasanataupen garahanterkaitpenggunaanteknologiinformasi yang lebihmeluas.

2. Variabel FaktorKeluarga $\left(\mathrm{X}_{2}\right)$ yang harus ditingkatkan adalah pada instrumen no 9 yang mendapatkan skor rata-rata terendah sebesar 3,62. Pada instrumen ini agar orang tuadapatmenanyakantentangaktifitas pada saat di sekolah.

3. Variabel PrestasiBelajar(Y) yang harus ditingkatkan adalah pada instrumen no 5 yang mendapatkan skor rata-rata terendah sebesar 3,68. Pada instrumen ini 
JURNAL ILMIAH

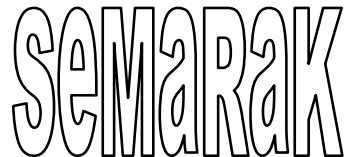

agarsiswa/ilebihmeningkatkanlagi

keinginanuntukberangkatbelajar di sekolah.

\section{DAFTAR PUSTAKA}

Abdulhak, H. I. \& Sanjaya, W. 2005. Media Pendidikan: SuatuPengantar. Bandung:

Pusat Pelayanan dan Pengembangan

Media Pendidikan UPI Bandung.

Aldi Atwinda Jauhar, NuristSurayyaUlfa,

TandiyoPradekso, AgusNaryoso. 2015.

PengaruhIntensitasPenggunaan

Smartphone dan KomunikasiOrangtua

Anak TerhadapPrestasiBelajar Anak.

Interaksi Online Vol. 11 No. 3 Hal. 1-16.

Anshori, Sodiq. 2017. Pemanfaatan TIK

SebagaiSumber Dan Media

Pembelajaran Di Sekolah. Civic-Culture:

JurnalIlmu Pendidikan PKn dan

SosialBudaya Vol. 1 No. 1 Hal. 10-20.

Arikunto, Suharsimi. 2012. ProsedurPenelitian.

Jakarta: RinekaCipta.

Asmani, Jamal Ma'mur. 2011. Tips

PemanfaatanTeknologiInformasi dan

Komunikasidalam Dunia Pendidikan.

Yogyakarta: DIVA Press.

Dessy Dwi Ariyani, Karunia Puji Hastuti, Eva

Alviawati.

2014.

PengaruhPemanfaatanTeknologiInforma

si Dan Komunikasi (TIK)

SebagaiSumberBelajarTerhadapPrestasi

BelajarSiswa Di SMP Negeri 15

Banjarmasin. JPG (Jurnal Pendidikan

Geografi) Vol. 1 No. 3 Hal. 51-58.
Fitriastuti, Pamulang

Febriani.

2013.

PengaruhInteraksiSosialDalamKeluarga

Dan

MinatBelajarSiswaTerhadapPrestasiBela

jarSiswa. OIKONOMIA - Jurnal

Pendidikan Ekonomi Vol. 2 No. 3 Hal. 183-188.

Ghozali, Imam. 2011. AplikasiAnalisis

Multivariate Dengan Program SPSS.

Semarang: Badan

PenerbitUniversitasDiponegoro.

2013. AplikasiAnalisis

Multivariate Dengan Program SPSS.

EdisiKetujuh. Semarang: Badan

PenerbitUniversitasDiponegoro.

Hamzah B. Uno dan Nina Lamatenggo. 2011.

TeknologiKomunikasi dan

InformasiPembelajaran. Jakarta: PT

BumiAksara.Media.

JazibPeasojo, $\quad$ Retmono. 2014.

PengaruhPerhatian Orang Tua Dan

KedisiplinanBelajarTerhadapPrestasiBel

ajar Mata Pelajaran IPS. Jurnal

Pendidikan Ekonomi IKIP Veteran

Semarang Vol. 2 No. 1 Hal. 1-11.

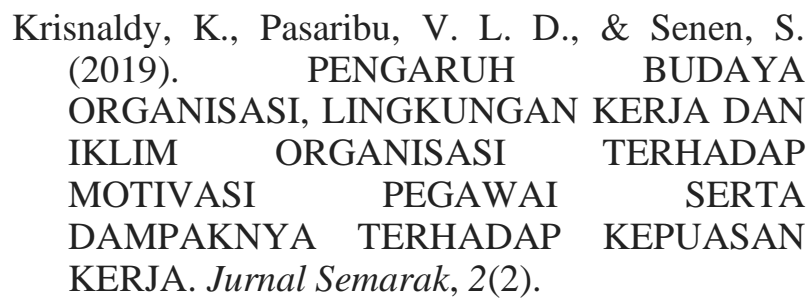

Lantipdan Riyanto. 2011. TeknologiInformasi Pendidikan. Yogyakarta: Gava Media. 
JURNAL ILMIAH

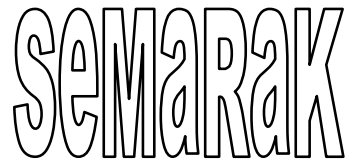

Made
P-ISSN 2615-6849, E-ISSN 2622-3686

Jurnal Semarak,Vol. 3,No.1, Februari 2020, Hal (60- 74)

@Prodi Manajemen Fakultas Ekonomi Universitas Pamulang
Alit,
2003.

KontribusiFaktorLingkunganSekolah,

LingkunganKeluarga,

dan

motivasiBerprestasiterhadap Nilai

Modern SiswaSekolahLanjutan Tingkat

Pertama (SLTP) Di KabupatenGianyar,

Bali. JurnalPenelitian dan Evaluasi Vol.

5 No. 6 Hal. 13-44.

Munir.

2009.

PembelajaranJarakJauhBerbasisTeknolo

gilnformasi dan Komunikasi. Bandung:

Alfabeta.

Nilan Tresnati, $\quad$ Kristika. 2016.

HubunganLingkunganKeluarga dan

MinatBelajarTerhadap Hasil Belajar IPS

Siswa Kelas IV SD di GugusKresna dan

ShintaKecamatan Semarang Barat.

Skripsi.

Nurlaela.

2014.

PengaruhKondisiEkonomiKeluarga Dan

PrestasiBelajarTerhadapMinatBerwiraus

ahaSiswa SMA. OIKONOMIA - jurnal

Pendidikan Ekonomi Vol. 3 No. 1 Hal.

1-7.

Pasaribu, V. L. D., \& Krisnaldy, K. (2018). ANALISIS KEPUASAN JAMA'AH PADA KINERJA DEWAN KEMAKMURAN MASJID ALHIDAYAH PERIODE TAHUN 2017. KREATIF: Jurnal Ilmiah Prodi Manajemen Universitas Pamulang, 6(4), 41-51.

Pasaribu, V. L. D., Krisnaldy, K., \& Warasto, H. N. (2020). Pengaruh Gaya Kepemimpinan, Disiplin Kerja Dan Kompensasi Terhadap
Kinerja Pegawai (Studi kasus kelurahan Pisangan Ciputat). Disrupsi Bisnis, 3(1).

Priatna,

Asep.

2011.

PengaruhPenerapanteknologiInformasi

(TIK)

TerhadapPrestasiBelajarSiswa Pada

kelasAkselerasi. JurnalAdministrasi

Pendidikan Vol. 13 No. 1 Hal. 1-8.

Ridwan, \&Sunarto. 2012. PengantarStatistika

Pendidikan, Sosial, Ekonomi,

Komunikasi, dan Bisnis. Bandung:

Alfabeta.

Saleh, Minhayati. 2014. PengaruhMotivasi, FaktorKeluarga, LingkunganKampus Dan

AktifBerorganisasiTerhadapPrestasiAka demik. Jurnal PHENOMENON Vol. 4 No. 2 Hal. 109-141.

Sanusi, Anwar. 2012. MetodePenelitianBisnis. SalembaEmpat. Jakarta.

Siregar, Syofian.

2015.

StatistikaTerapanuntukPerguruan Tinggi.

Jakarta: PT Kharisma Putra Utama.

Sri Rahmadani, Gusnardi, Hendripides. 2017. PengaruhFaktorLingkunganKeluargaTer hadapPrestasiBelajarSiswa Pada Mata Pelajaran Akuntansi Kelas XI Di SMK Muhammadiyah 2 Pekanbaru. Jurnal Online MahasiswaFakultasKeguruan dan Ilmu Pendidikan Vol. 4 No. 1 Hal. 1-9.

Sugiyono. 2012. MetodePenelitianBisnis. Bandung :Alfabeta. 
JURNAL ILMIAH

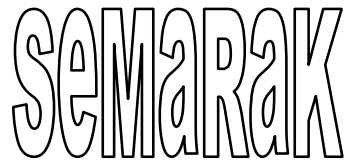

P-ISSN 2615-6849, E-ISSN 2622-3686

Jurnal Semarak,Vol. 3,No.1, Februari 2020, Hal (60- 74)

@Prodi Manajemen Fakultas Ekonomi Universitas Pamulang

2014. MetodePenelitian

PendekatanKuantitatif,

Pendidikan

Kualitatif Dan R\&D. Bandung: Alfabeta.

2015. MetodePenelitian

Pendidikan (PendekatanKuantitatif,

Kualitatif dan R\&D). Penerbit CV.

Alfabeta: Bandung.

2016.

MetodePenelitianKuantitatifKualitataif

dan Kombinasi (Mixed Methods).

Bandung: Alfabeta. . 2016. MetodePenelitianKuantitatif,

Kualitatif dan R\&D. Bandung: PT

Alfabet.

Sujoko. 2013. PemanfaatanTeknologiInformasi dan Komunikasisebagai Media Pembelajaran di SMP Negeri 1

GegerMadiun. JurnalKebijakan dan Pengembangan Pendidikan Vol. 1 No. 1

Hal. 71-77.

Surya, Mohamad. 2004. PsikologiPembelajaran dan Pengajaran. Bandung: Pustaka Bani Quraisy.

Suyanto. 2005.

PengantarTeknologiInfomasiUntukBisni

s. Andi. Yogyakarta.

Syah, Muhibbin. 2008. Psikologi Pendidikan.

Bandung. PT RemajaRosdakarya.
Warsita,

Bambang.

2008.

TeknologiPembelajaran:

Landasan\&Aplikasinya, Jakarta: Rineka.

Wijaya Anggita, Langgeng. 2012.

PengaruhPenggunaanTeknologiInformas

iTerhadapPrestasiAkademikMahasiswa

.Jurnal Pendidikan Akuntansi: (JPA)

Vol. 1 No. 2 Hal. 1-13.

Wulandari, Diah.

2017.

PengaruhLingkunganKeluarga dan

MinatbelajarTerhadaPPrestasiBelajarmat ematikaSiswakelas III di SDN 1

NglandungGegermadiunTahunPelajar

2016/201. Skripsi.

Yasin, Sanjaya.

2016.

PengertianKeluargaFungsiFaktor-

faktordalamLingkungan

Keluarga.http://www.sarjanaku.com/201

3/04/pengertian-keluarga-fungsi-

faktor.html. Diaksestanggal 30 Agustus 2019.

Yusri. 2016. PengaruhPenggunaan Media TeknologiInformasi Dan Komunikasi (TIK) DenganPrestasiBelajar Bahasa InggrisPesertaDidik Kelas X Di SMAN I DekaiKabupatenYahukimo. JurnalIlmiah ILKOM Vol. 8 No. 1 Hal. 49-56. 